\title{
Gender differences in online collaborative learning groups promoting affective education and social capital
}

\section{Gender differences and social capital in collaborative learning groups}

\author{
Mebane Minou Ella \\ Sorace Roberta \\ Solimeno Andrea \\ Tomai Manuela
}

\begin{abstract}
This paper reports the results of a study aimed to establish whether the amount and types of conflicts vary in all male, all female and mixed gender groups working in asynchronous collaborative learning online settings. Sixty psychology majors were divided into three groups conducted online by the same teacher. The study show that the levels of participation in the three groups varied in relation to gender composition. Further the results evidenced all female group did have more conflicts then male and mixed groups, but primarily they did not have interpersonal. The female groups' conflicts seem to be related to goal-oriented process of work.

Keywords: Affective education; Human sex differences; Learning.
\end{abstract}

\section{Diferença de gênero em grupos de aprendizagem colaborativa online promovendo educação afetiva e capital social}

\section{Resumo}

Esse artigo apresenta os resultados de um estudo destinado a estabelecer os tipos e a quantidade de conflitos existentes entre homens, mulheres e grupos mistos que atuam de modo assíncrono num modelo de aprendizagem colaborativa online. 60 psicólogos especialistas foram divididos em três grupos de trabalho online orientados pelo mesmo professor. $\mathrm{O}$ estudo mostra que os níveis de participação nesses grupos distintos variaram com relação a composição genérica dos mesmos. Além disso, os resultados evidenciaram que todos os grupos femininos revelaram um número muito maior de conflitos em comparação aos formados apenas por homens ou mistos, mas primariamente não apresentaram conflitos interpessoais. Os conflitos dos grupos femininos eram relacionados com a escolha da meta do processo de trabalho.

Palavras-chave: Educação afetiva; Diferenças de gênero; Aprendizagem.

\section{Diferencia de género en grupos de aprendizaje de ayuda online promoviendo educación afectiva y capital social}

\section{Resumen}

Este artículo presenta los resultados de un estudio destinado a establecer los tipos y la cantidad de conflictos existentes entre hombres, mujeres y grupos mixtos que actúan de modo asíncrono en un modelo de aprendizaje de ayuda online. 60 psicólogos especialistas fueron divididos en tres grupos de trabajo online orientados por el mismo profesor. El estudio muestra que los niveles de participación en esos diferentes grupos variaron con relación a la composición genérica de los mismos. Además de eso, los resultados mostraron que todos los grupos femeninos revelaron un número mucho mayor de conflictos en comparación a los grupos formados apenas por hombres o a los grupos mixtos, siendo que en primer lugar no presentaron conflictos interpersonales. Los conflictos de los grupos femeninos eran relacionados con la elección de la meta del proceso de trabajo.

Palabras clave: Educación afectiva; Diferencias de género; Aprendizaje. 


\section{Introduction}

In recent years interest in affective education has risen: as levels of violent and antisocial behaviours have increased in many schools, more teachers have become concerned both with helping adolescents learn to cope with interpersonal conflict and negative emotions and with promoting the creation of social capital (Adler \& Kwon, 2002; Caprara \& Gerbino, 2002; Leonard, 2004; Loeber \& Ferrington, 1998; Kavanaugh, Reese, Carroll \& Rosson, 2005; Putnam, 2000). Affective education has been defined as that part of the educational process that regards attitudes, feelings, beliefs and emotions of students, and its proponents have developed tools to promote prosocial behaviours and the formation of bonding social capital (Francescato \& Putton, 1995; Lang, Katz \& Menezes, 1998). Gittell and Vidal (1998) define bonding social capital as "the type that brings closer together people who already know each other" ( $p$. 15); it refers to resources that people can obtain from within-group ties, while bridging social capital is "the type that brings together people or groups who previously did not know each other" (p. 15).

Among the methodologies developed by affective educators to promote bonding social capital, and conflict resolution, the most well known is the "circle time", where students sit in circle, facing one another and discuss topics of their choice. Several studies have shown that use of circle time promotes prosocial behaviours, better peer relations, reduces exclusion, fosters mutual aid, and promotes self esteem, self awareness, and awareness of other's feelings (Karpinnen, Katz \& Neill, 2005). Training teachers, psychologists and other educators to use affective education competently, has been up to now, very time consuming and expensive, requiring intensive face-toface small groups meetings. However the new platforms for e-learning permit forms of collaborative learning online such as Computer Supported Collaborative Learning (CSCL), which could be used to provide professional training that requires small group settings.

Most training programs for clinical or educational psychologists still rely almost exclusively on the face- to-face approach, and several authors doubt that computer networks can replace the personal touch in training students (Belar, 1998). However some authors (Harasim \& Yung, 1993; Rudestam, 2004) theorize that key features of CSCL such asynchronous small group discussions, collaborative problems solving, reflective inquiry, competency based outcomes and the facilitator role of the instructor could be very helpful in the training of clinical psychologists. Others (Binder, 1999) have also hypothesized that the use of interactive, multimedia computer technology to simulate live clinical experience can guide the learner through staged difficulties.

Some empirical studies have shown that various professional competencies in the fields of family therapy (Maggio, Chenail \& Todd, 200I), industrial psychology (Vodanovich \& Piotrowski, 1990) and educational psychology (Tolmie \& Boyle, 2000) can be learnt online, but they have lacked control face-toface groups.

So the review of the literature shows the need to ascertain whether certain specific skills, such as those required in affective education, can be moved beyond the traditional classroom and to evaluate how online and face-to-face settings fare in transmitting specific professional skills and promoting social capital, keeping constant certain key variables such as teachers' and students' characteristics, collaborative learning modalities used, and evaluation procedures. There is also the need to find out if social presence and social capital can be built more and last more in face-to-face affective education collaborative learning settings or CSCL contexts.

In a previous study (Mebane, Porcelli, lannone, Attanasio \& Francescato, in press) we confirmed that CSCL could be used to teach some professional psychological skills of affective education as well as in face-to-face control groups. These included a mix of theoretical knowledge about principles and methods of affective education, and the development of professional competences such as being able to facilitate circletimes, and observing and understanding group processes. Forty seven university clinical and community psychology master program majors, $85 \%$ females, matched for age, and academic achievement 
were randomly divided into two groups, and met with the same teacher for three months for face-to-face or online circle times and other socioaffective collaborative group activities.

We used Yahoo groups platforms because it was cost free. Analysis of variance for a mixed design was performed having as independent factors type of groups (face-to-face and online). The results of this study showed that online students acquired the theoretical knowledge about principles and methods of affective education and competences in facilitating circle times, and observing group processes just as much as their face-to-face colleagues.

A follow-up interview nine months after the end of the seminar was undertaken to assess whether social bonds, formed during the seminars, had lasted in time. Analysis of student's replies showed that bonding social capital had developed during the seminars. Students in both groups made at least one new close friend during the seminar. But online students also developed more lasting social capital: after nine months they met face-to-face with the new friends made through the seminars and studied together more often than their face-to-face colleagues.

Since our students were mostly females, we wondered whether the creation of bonding social capital could be attributed to gender of participants as well as to collaborative learning online, since several studies show gender differences in online communication.

Gendered communication in synchronous and asynchronous online settings

Early psychological studies of the Internet focused on what was lost in text-based CMC and theorised that self-awareness was reduced in CMC and that communication will be depersonalised, less 'social' and more uninhibited, in comparison to face-to-face communication (Nie, 200I; Nie, Hillygus \& Erbring, 2002). On the contrary, a large part of recent literature maintains that computer mediated communication liberates interpersonal relationships from the limits of physical locality and thus creates novel opportunities for the development of genuine relationships and social capital (Horrigan \& Rainee, 2002; Parks \& Floyd, 1996; Parks \& Roberts, 1998). In particular, asynchronous communication online is conceived to give to the students ample time to consult source material and analyse the comments of others before contributing (posting) their own views; this process makes them more reflective and deliberate in their discussion, develops self-awareness, interpersonal awareness, and the appreciation for diverse perspectives, therefore favouring critical thinking (Rudestam, 2004; Sipusic, Pannoni, Smith, Dutra, Gibbons \& Sutherland, 1999).

For these reasons many authors have hypothesized that Computer Mediated Communication facilitates cooperation and communication, such diminishing interpersonal conflicts (Griffith \& Meader, 2004; Griffith, Mannix \& Neale, 2003; Mortsen \& Hinds, 200I; Potter \& Balthazard, 2002; Rudestam, 2004). However most of these studies do not take into account the influence of variables such as gender and type of communication, synchronous vs asynchronous.

In fact, one important limit of several previous studies on conflict online is that they either used both synchronous and asynchronous communication as if they were equivalent (Johnson, Suriya, Won Yoon, Berret \& La Fleur, 2002; Mortsen \& Hinds, 200I), or did not clearly specified if they evaluated the amount of conflict during synchronous and asynchronous communication (Griffith et al., 2003; Griffith \& Meader, 2004). We believe, instead, the type CMC used may be a crucial factor in promoting or reducing conflict; online synchronous environments, in fact, replicate some of the characteristics of a traditional class discussion: too many messages coming across may make people feel overwhelmed, confused, or interrupted in their own thinking processes, fostering negative emotions, which may increment relational and process conflicts. A few empirical studies seem to point in the direction that asynchronous $\mathrm{CMC}$, making the expression of emotions less immediate, may foster communication patterns that lead less often to conflict. Fahy (2005) compared the online and face-to-face group interaction using Bales' Interaction Process Analysis (IPA). The online group showed considerably less negative socio-emotional behaviour; particularly two types of behaviour of IPA, show tension and show 
antagonism, were not observed in the online group at all. Another study (Chou, 2004) have found asynchronous groups participants compared to synchronous ones more likely to express more opinions, to give information and to answer questions rather than contesting other people's opinions. Johnson et al. (2002) found that online asynchronous learning groups follow a sequential model of group development, but do not present the conflict stage.

We confirmed Johnson's findings in a study of asynchronous team work: we found fewer episodes of conflict in online than in face-to-face student groups and the lack of a storming stage, commonly found in face-to-face groups (Tomai, Mebane, Foddis, Ingravalle \& Francescato, in press). The low level of conflict found in our asynchronous groups could be due to the combined effect of using collaborative methodologies, which emphasize cooperation more than competition, and of employing asynchronous communication modalities, which may foster less conflict among members. However since also in this study, our students were mostly females (females make up $85 \%$ of psychology students in Italy), the low prevalence of conflict could be due also to gender differences as some studies seem to suggest.

Studies on gender differences in online settings have focused primarily on two topics: interaction patterns and participation levels. Some studies have also explored gender difference in computer use: earlier studies had found males to have an advantage (Adam \& Bruce, 1993; Collazos, Guerrero, Llana \& Oetzel, 2002; Kirk, 1992; Yelloushan, 1989) while more recent studies did not find any gender differences (Hargittai \& Shafer, 2006; Torkzadeh \& Van Dyke, 2002).

\section{Interaction patterns}

Several studies show that patterns of communication online differ with the gendered composition of group members. Blum (1999) found that women more than men, in training groups online, were more supportive, more able to perceive moods and to disclose personal information. Other studies (Anderson \& Blanchard, 1982; Carli, 1989; Eagly \& Karau, 199I; Savicki, Kelley \& Ammon, 2002) show that women will primarily assume maintenance or socio-emotional group process roles and men will take one more task oriented roles.

Therefore one could predict that social capital formation may be influenced by the gender composition of online training groups. We found no research related to this topic, however several studies have analyzed what variables contribute to create conflictive relations in groups, sometimes preventing the formation of positive social bonds which are the basis on which social capital is built.

Savicki, Kelley and Lingenfelter (1996) have found specific communication differences related to gender composition in small (4 to 6 member) groups using asynchronous CMC over 3 to 4 week periods to complete specific tasks. These results are consistent with both task versus socio-emotional contrasts and with Herring's (1994) findings. The author describes different gender styles. As Tannen (199I) had described in face-to-face contexts, consistent with the task versus socio-emotional distinction, the female style is characterized by supportiveness and attenuation while the male style by adversariality (strong assertions, lengthy and/or frequent postings, self-promotion, and sarcasm; coarse and abusive language). Herring (1994) suggested that gender-based communication styles and the power dynamics associated with these styles carry over to electronic environments, despite the loss of overt face-to-face cues to gender; males are traditionally awarded more status and power in society and these gendered power differentials in communication style would transfer into computer-mediated environments as also Sussman and Tyson (2000) suggested.

However Guiller and Durndell (2007) found that males and females were similar regarding use linguistic variables, with the exception of intensifiers, as more females used them than males. Further, males were more likely than females to use authoritative language and to respond negatively in interaction, and females more than males tended to explicitly agree and support others and make more personal and emotional contributions. The authors underline that it is still unclear whether CMC moderates or magnifies the gender differences reported in faceto-face research. 


\section{Participation Patterns}

The absence of hierarchy, status and power in CMC, was also presumed to have a democratising effect on participation (Sproull \& Kiesler, 1986). It was suggested that in CMC participants become uninhibited and participated more. The removal of status cues such as gender has the potential to moderate the effects of gender on language use online. Several studies have examined participation in CMC by gender with conflicting results (Graddol \& Swan, 1989; Selfe \& Meyer, 1991). Males dominated mixed-sex interaction in formal face-toface contexts by speaking more frequently, for longer and interrupting more, than females (Tannen, 199I; Thorne, Kramarae \& Henley, 1983). On the contrary, Miller and Durndell (2004) studied participation in an educational context and found no significant gender differences in measures of participation (frequency or length of online postings) of males and females. However, other studies have shown that relatively few males still managed to dominate a discussion online (Light, Nesbitt, Light \& Burns, 2000; Sierpe, 2000).

Gender seems to determine not only the interaction style but also group development (Savicki et al., 1996); in fact women in female only groups (FO) had more advanced levels of group development than did either male only (MO) or evenly mixed gender (MIX) groups. Female groups seem to develop more trust among members favouring a more direct and personal communication. Also members of female groups show a higher capacity to question and modify their opinion.

So a review of the literature shows the need to explore gender differences in conflict in online groups, controlling for pedagogical model used (individual vs collaborative learning) and communication mode (synchronous vs. asynchronous).

\footnotetext{
Aims

Our study aimed, therefore, to establish whether the amount and types of conflicts vary in all male, all female and mixed gender groups working in asynchronous collaborative learning online settings.
}

\section{Method}

Sixty psychology majors matched for age, academic achievement, problem solving-strategies, attitudes toward collaborative learning and toward group work, were divided into three groups, one with only females, one with only males and one with both male and female members. In the first two weeks students worked in one large groups, in the last three weeks they also worked in small (4-5 participants) subgroups. The same teacher, expert in both faceto-face and online teaching, structured affective education learning activities that could be done weekly in all three seminars. We planned micro modules with precise didactic objectives and group tasks that required high degree of cooperation. Two trained observers, recorded online groups processes, plus all exchanges were automatically recorded on the platforms. Students in all three seminars had access to the same theoretical materials on affective education and the same practice exercises and received feedback from the same teacher. In all groups they experienced first circle times facilitated by the teacher and then students conducted the other circle times with some students acting as silent observers outside the circle time. They also practiced analyzing group processes, and detecting strong and week points. Students were assessed using a variety of evaluations procedures: individual multiple choice exams, individual competency based performances, and essays written cooperatively in small groups (four to five students) to reinforce collaborative learning skills of their group activities.

We used forum and mailing list of a Moodle platform, and all students were trained in using the platform. In two previous studies on online learning (Francescato, Porcelli, Mebane, Cuddetta, Klobas \& Renzi, 2006; Francescato, Mebane, Porcelli, Attanasio \& Pulino, 2007) we had not found any gender differences among our students in computer use, and again this year there was no difference.

To analyze the groups' process we used Tuckman's (1965) five phase model while we referred to Jehn typologies $(1995 ; 1997)$ to explore which types of conflicts arose more frequently. She distinguishes 
among relational, task and process conflicts. Relational conflict includes personality clashes, hostility and opinions divergences ("they reproached us but I know that we have nothing to envy others for"). Task or cognitive conflict is characterized by the presence of different opinions among group members on what goals to pursue and how ("I can't wait for your response until tomorrow! Next time we have to have clearer aims and organize ourselves better!"). Process conflict deals with disagreement on how to carry on a group tasks or on how to distribute resources ("I'm not agree! Too much work for us and too little for you!"). We used content analysis of the entire corpus of email (Losito, 1996).

We are at present, a year after the end of this research, conducting a follow up study to gauge eventual differences in social capital formation, in all males, all females and mixed groups.

\section{Results}

In all three groups, analyzing exchanges in the larger group forum setting, there was not a phase of storming. Most interactions happened during the norming and performing stages, that is when participants were engaged in proposing rules and procedures deciding objectives and focusing on reaching them. However the levels of participation in the three groups varied as can be seen on Table I. The mixed group exchanged $5 \mathrm{II}$ mails, the only female group 293 and the male group had the lowest exchange (109).

The language used differed in the three groups. The all male group compared to the other two used less emoticons and colors and instead wrote more often foul words.

Considering all email exchanged in the small subgroup setting, as can be seen in Table 2 , the number of conflicts was greater in female than male and mixed groups. Therefore, in all three groups most conflicts are process ones. In particular in all female groups, conflict was around problems in performing tasks, or about scant participation on the part of some group members.

Examining the email exchanges in all subgroups evidenced the same results: as in the general forum, the storming phase was absent. In the small group

Table I: Participation in general forum in the different groups

\begin{tabular}{lcccccc}
\hline \multicolumn{7}{c}{ Participation } \\
\hline \multicolumn{1}{c}{ General forum } & 1 week & 2 week & 3 week & 4 week & 5 week & Total \\
\hline Male group & 15 & 7 & 23 & 40 & 24 & 109 \\
Female group & 22 & 37 & 85 & 80 & 69 & 293 \\
Mix group & 84 & 90 & 184 & 152 & 1 & 511 \\
\hline
\end{tabular}

Table 2: Kind of conflict in the different groups

\begin{tabular}{|c|c|c|c|c|c|c|c|c|c|c|c|c|c|c|c|}
\hline \multirow{2}{*}{ Kind of conflict } & \multicolumn{6}{|c|}{ Female group } & \multicolumn{4}{|c|}{ Male group } & \multicolumn{5}{|c|}{ Mixed group } \\
\hline & $\mathrm{Lg}$ & $\mathrm{Sg} 1$ & $\mathrm{Sg} 2$ & $\mathrm{Sg} 3$ & $\mathrm{Sg} 4$ & Lg & $\mathrm{Sg} 1$ & $\mathrm{Sg} 2$ & $\mathrm{Sg} 3$ & $\mathrm{Sg} 4$ & $\mathrm{Lg}$ & $\mathrm{Sg} 1$ & $\mathrm{Sg} 2$ & $\mathrm{Sg} 3$ & $\mathrm{Sg} 4$ \\
\hline Relational & 1 & 0 & 0 & 0 & 0 & 1 & 0 & 0 & 0 & 0 & 2 & 0 & 0 & 0 & 0 \\
\hline Task & 2 & 1 & 1 & 0 & 1 & 0 & 0 & 0 & 0 & 0 & 1 & 1 & 0 & 0 & 2 \\
\hline Proce & 5 & 17 & 6 & 0 & 6 & 5 & 2 & 2 & 0 & 2 & 3 & 7 & 4 & 2 & 1 \\
\hline Total & 8 & 18 & 7 & 0 & 7 & 6 & 2 & 2 & 0 & 2 & 6 & 8 & 4 & 2 & 3 \\
\hline
\end{tabular}

$\mathrm{Lg}=$ larger group; $\mathrm{Sg}=$ sub group 
setting, as can be seen in Table 3, the all female group exchanged the highest number of email, confirming that, also online, women tend to speak up more in small groups than in larger ones, as they do in face-to-face settings. Moreover, the female subgroups were more relation oriented, more collaborative and more respectful of norms, while the all male groups were more task oriented and also kept better track of time spend and approaching deadlines. The fact that female groups were more respectful of norms and dealt with conflicts openly could have favoured the higher participation rate that we found and also helped the group to survive and function. In fact, one male subgroup, which had very few mail exchanges, the lowest number of all subgroups, as can be seen on Table 3, saw three people leave so that the remaining two joined other groups.

Also in the subgroups the exchange of email occurred more in the norming and performing stages. Again, we found differences in the language used: in the male subgroups, members told jokes, kidded around and used irony more than members of the other two groups.

\section{Discussion}

Overall, our results evidenced the lack of a storming phase in all plenary groups and also in all subgroups regardless of gender composition, confirming Johnson's et al. (2002) findings and Tomai et al. (in press) results. We also found few conflictual episodes distributed along all phases of group development. Asynchronous communication seems to foster a cooperative atmosphere as Chou (2004), Griffith et al. (2003) and Rudestam (2004) maintained, at least in groups using a collaborative learning methodology. These results can have important educational implications, if we want to foster constructive communication among potentially adversary groups, such in intercultural education, using collaborative methodologies in asynchronous online settings seems to be a promising strategy.

Our study also shows, however, that gender composition can make a further difference even in collaborative asynchronous settings, but not entirely in the direction, of women being less confrontational than men as women have been found to be in some face-to-face and online settings (Light, Nesbitt, Light

Table 3: Participation in subgroup forum in the different groups

\begin{tabular}{lccccc}
\hline Participation & & 3 week & 4 week & 5 week & Total \\
\hline \multirow{3}{*}{$\begin{array}{l}\text { Male } \\
\text { subgroup }\end{array}$} & $1^{\circ}$ & 41 & 132 & 290 & 463 \\
forum & $3^{\circ}$ & 12 & 51 & 7 & 70 \\
& $4^{\circ}$ & 7 & 7 & 0 & 14 \\
\hline & $1^{\circ}$ & 18 & 128 & 24 & 170 \\
Female & $2^{\circ}$ & 79 & 66 & 80 & 225 \\
subgroup & $3^{\circ}$ & 38 & 174 & 295 & 507 \\
forum & $4^{\circ}$ & 28 & 65 & 318 & 411 \\
& $1^{\circ}$ & 31 & 21 & 19 & 71 \\
& $2^{\circ}$ & 46 & 45 & 65 & 156 \\
Mix & $3^{\circ}$ & 35 & 29 & 24 & 88 \\
subgroup & $4^{\circ}$ & 39 & 28 & 16 & 83 \\
forum & $4^{\circ}$ & 96 & 87 & 55 & 238 \\
\hline
\end{tabular}


\& Burns, 2000; Tannen, 1991; Thorne, Kramarae \& Henley, 1983; Sierpe, 2000).

Further studies will have to confirm if online all female groups do have, as we detected, more conflicts than mixed or male groups. This was a rather surprising new finding since most authors had previously ascertained that women's communication style was characterised by supportiveness and attenuation of contrast (Herring, 1994; Tannen, 1991). We should underline that our all female group did have more conflicts but primarily they did not have interpersonal. Their conflicts seem to be related to goal-oriented process. These types of conflict can lead to better performances, in fact, several authors maintain that facing conflicts allows for more participation, group development and more thoughtful decision making processes (Griffith et al., 2003; Rudestam 2004; Savicki et al., 1996). Further studies can explore where task related conflicts are more prevalent in all females, mixed or all male groups and how this affects performance and social capital's formation.

Our study showed that men in all male groups participated less often and used more foul and abusive language. In at least one male subgroup this lead to a premature death of the group and therefore to lower performance and lower initial social capital, since new social ties were severed. Further studies should confirm if these gender differences are only found among psychology university students, where males represent a minority group, or do appear also in all male groups in other business, political or recreational contexts, where men are the majority.

\section{References}

Adam, A., \& Bruce, M. (1993). The expert systems debate: A gender perspective. In E. Green, J. Owen \&D. Pain (Eds), Gendered by design? (pp. 8I-94). Washington, D.C.: Taylor \& Francis.

Adler, P. S., \& Kwon, S. W. (2002). Social capital: Prospects for a new concept. Academy of Management Review, 27(I), 17-40.

Anderson, L. R., \& Blanchard, P. N. (1982). Sex differences in task and social-emotional behavior. Basic and Applied Social Psychology, 3, 109-139.
Belar, C. D. (1998). Graduate education in clinical psychology: "We are not in Kansas anymore". American Psychologist, 53, 456-464.

Binder, J. L. (1999). Issues in teaching and learning time-limited psychodynamic psychotherapy. Clinical Psychological Review, 19, 705-719.

Blum, K. (1999). Gender differences in asynchronous learning in higher education: Learning styles, participation barriers and communication patterns. Journal of Asynchronous Learning, 3(I), 46-66.

Caprara, G. V., \& Gerbino, M. (2002). Determinanti personali del fallimento scolastico: correlati, antecedenti e conseguenze della bocciatura. Età evolutiva, 73, 18-33.

Carli, L. L. (1989). Gender differences in interaction style and influence. Journal of Personality and Social Psychology, 56, 565576.

Chou, C. C. (2004). A Model of Learner-Centered ComputerMediated Interaction For Collaborative Distance Learning. International Journal on E-learning, I, I I- I8.

Collazos, C., Guerrero, L., Llana, M., \& Oetzel, J. (2002). Gender: An Influence Factor in the Collaborative Work Process. Proceedings of the $4^{\text {th }}$ International Conference on New Educational Environment (ICNEE 2002), Lugano, Switzerland, May, 2002, pp. 7-10).

Eagly, A. H., \& Karau, S. J. (1991). Gender and emergence of leaders: a meta-analysis. Journal of Personality and Social Psychology, 60, 685-7I0.

Fahy, P. J. (2005). Online and Face-to-Face Group Interaction Processes Compared Using Bales' Interaction Process Analysis (IPA). European Journal of Open Distance and E-Learning.

Francescato, D., Mebane, M.E., Porcelli, R., Attanasio C., \& Pulino M. (2007). Developing professional skills and social capital through computer supported collaborative learning in university contexts. International Journal of Human-Computer Studies, 65(2), I40-152.

Francescato, D., Porcelli, R., Mebane, M.E., Cuddetta, M., Klobas, J., \& Renzi, P. (2006). Evaluation of the efficacy of collaborative learning in face-to-face and computer-supported university contexts. Computers in Human Behavior, 22, 163-176.

Francescato, D., \& Putton, A. (1995). Star meglio insieme. Oltre l'individualismo. Milano, Mondadori.

Gittell, R., \& Vidal, A. (1998). Community Organizing: Building Social Capital as a Development Strategy. Thousand Oaks, CA: Sage. 
Graddol, D., \& Swan, J. (1989). Gender voices. Cambridge, MA: Basil Blackwell.

Griffith, T. L., Mannix, E.A. \& Neale, M.A. (2003). Conflict and virtual teams. In S. G. Cohen \& C. B. Gibson (Eds.), Virtual teams that work (pp. 335-352). San Francisco: Jossey-Bass.

Griffith, T. L., \& Meader, D. (2004). Prelude to virtual groups: Leadership and technology in semi-virtual groups. In D. Pauleen (Ed.), Virtual teams: Projects, protocols and processes (pp. 23 I254). Hershey, PA: Idea Group.

Guiller, J., \& Durndell, A. (2007). Students' linguistic behaviour in online discussion groups: Does gender matter? Computers in Human Behavior, 23, 2240-2255.

Harasim, L. M., \& Yung, B. (1993). Teaching and learning on the Internet. Burnaby, British Columbia, Canada: Simon Fraser University, Department of Communication.

Hargittai, E., \& Shafer, S. (2006). Differences in Actual and Perceived On line Skills: The Role of Gender. Social Science Quarterly, 87, 432-448.

Herring, S. C. (1994). Gender differences in computermediated communication: bringing familiar baggage to the new frontier [On-line]. http://www.eff.org/pub/Net_culture/ Gender_issues/cmc_and_gender Accessed 3.12.99.

Horrigan, J. B., \& Rainee, L. (2002, October 13-16). Getting Serious Online. Paper presented at the Internet Research 3.0, Maastricht, The Netherlands.

Jehn, K.A. (1995). A multimethod examination of the benefits and detriments of intragroup conflict. Administrative Science Quarterly, (40:2), 256-282.

Jehn, K. A. (1997). A qualitative analysis of conflict types and dimensions in organizational grous. Administrative Science Quaterly, 42, 530-557.

Johnson, S. D., Suriya, C., Won Yoon, S., Berret, J. V., \& La Fleur, J. (2002). Team development and group process of virtual learning teams. Computers \& Education, 39, 379-393.

Karpinnen, S., Katz, Y., \& Neill, S. (Eds.). (2005). Theory and practice in Affective education. Helsinki: University of Hensinki.

Kavanaugh, A. L., Reese, D. D., Carroll, J. M., \& Rosson, M. B. (2005). Weak ties in networked communities. The Information Society, 2 I(2), II9-I3I.

Kirk, D. (1992). Gender issues in information technology as found in schools. Educational Technology, 32, 28-31.

Lang, P., Katz, Y., \& Menezes I. (1998). Affective education. A comparative view. London and New York: Cassell.
Leonard, M. (2004). Bonding and bridging social capital: Reflections from Belfast. Sociology: The Journal of the British Sociological Association, 38(5), 927-944.

Light, V., Nesbitt, E., Light, P., \& Burns, J. R. (2000). 'Let's you and me have a little discussion': computer mediated communication in support of campus-based university courses. Studies in Higher Education, 25, 85-96.

Loeber, R., \& Ferrington, D. (Eds.). (1998). Serious and violent juvenile offenders: risk factors and successful interventions. Thousand Oaks: Sage.

Losito, G. (1996). L'analisi del contenuto nella ricerca sociale. Franco Angeli, Milano.

Maggio, L. M., Chenail, R., \& Todd, T. (200I). Teaching family therapy in an electronic age. Journal of Systemic Therapies, 20(I), 12-23.

Mebane, M. E., Porcelli, R., lannone, A., Attanasio, C., \& Francescato, D. (in press). Evaluation of the efficacy of affective education online training in promoting academic and professional learning and social capital. International Journal of Human-Computer Interaction, 2, 263-28I

Miller, J., \& Durndell, A. (2004). Gender, language and computer-mediated communication. In K. Morgan, C. A. Brebbia, J. Sanchez \& A. Voiskounsky (Eds.), Human perspectives in the Internet society: culture, psychology and gender (pp. 235244). Southampton: WIT Press.

Mortsen, M., \& Hinds, P. J. (200I). Conflict and shared identity in geographically distribuited teams. Journal of Conflict Management, (12:3), 212-238.

Nie, N. H. (200I). Sociability, interpersonal relations, and the Internet: Reconciling conflicting findings. American Behavioral Scientist, 45(3), 420-435.

Nie, N. H., Hillygus, D. S., \& Erbring, L. (2002). Internet use, interpersonal relations, and sociability: A time diary study. In B. Wellman \& C. Haythornthwaite (Eds.), The Internet in Everyday Life (pp. 216-243). Malden, MA: Blackwell.

Parks, M. R., \& Floyd, K. ( 1996). Making friends in cyberspace. Journal of Communication, 46(I), 80-97.

Parks, M. R., \& Roberts, L. D. (1998). "Making Moosic”: the development of personal relationships online and a comparison to their off line counterparts. Journal of Social and Personal Relationships, 15(4), 517-537.

Potter, R. E., \& Balthazard, P. A. (2002). Virtual team interaction styles: assessment and effects. International Journal HumanComputer Studies, 56, 423-443. 
Putnam, R. (2000). Bowling Alone the Collapse and Revival of American Community. New York: Simon and Schuster.

Rudestam, K. E. (2004). Distribuited education and the role of online learning in training professional psychologist. Professional Psychology: Research Practice, 34(4), 427-432.

Savicki, V., Kelley, M., \& Ammon B. (2002). Effects of training on computer-mediated communication in single or mixed gender small task groups. Computers in Human Behavior, 18, 257-269.

Savicki, V., Kelley, M., \& Lingenfelter, D. (1996). Gender, group composition, and task type in small task groups using computer-mediated comunication. Computers in Human Behavior, 12, 549-565.

Selfe, C. L., \& Meyer, P. R. ( 99 I). Testing claims for on-line conferences. Written Communication, 8, 163-192.

Sierpe, E. (2000). Gender and technological practice in electronic discussion lists: an examination of JESSE, the library/ information science education forum. Library and Information Science Research, 22, 273-289.

Sipusic, M., Pannoni, R., Smith, R., Dutra, J., Gibbons, J., \& Sutherland, W. (1999). Virtual Collaborative Learning: A Comparison between Face-to-Face Tutored Video Instruction and Distributed Tutored Video Instruction (DTVI). Sun Microsystems Laboratories, Inc. TR-99-72. Available at http:// www.sun.com/research/techrep/I999/ abstract-72.html.

Sproull, L., \& Kiesler, S. (1986). Reducing social context cues: electronic mail in organizational communication. Management Science, 32, 1492-1512.
Sussman, N., \& Tyson, D. (2000). Sex and power: gender differences in computer-mediated interactions. Computers in Human Behavior, 16, 38I-394.

Tannen, D. (199I). You Just don't understand: women and men in conversation. London: Virago Press.

Thorne, B., Kramarae, C., \& Henley, N. (Eds.). (I 983). Language, gender and society. Rowley, MA: Newbury House.

Tolmie, A., \& Boyle, J. (2000). Factors influencing the success of computer mediated communication (CMC) environments in university teaching: A review and case study. Computers \& Education, 34, I19-140.

Tomai, M., Mebane M. E., Foddis, A., Ingravalle, V., \& Francescato, D. (in press). Do virtual groups experience less conflict than traditional teams? Computers in Human Behavior.

Torkzadeh, G., \& Van Dyke, T. P. (2002). Effects of training on Internet self efficacy and computer user attitudes. Computers in Human Behavior, I8(5), 479-494.

Tuckmann, B. (1965). Developmental sequence in small groups. Psychological Bulletin, 63, 384-399.

Vodanovich, S. J., \& Piotrowski, C. (1999). An Internet-based approach to legal issues in industrial-organizational psychology. Journal of Educational Technology Systems, 28(I), 67-73.

Yelloushan, K. (1989). Social barriers hindering successful entry of females into technology oriented fields. Educational Technology, 29, 44-46.

\section{About the authors}

Mebane Minou Ella (minou.mebane@uniromal.it): Faculty of Psychology 2, University Sapienza, Via Dei Marsi 78, 00185 Rome, Italy.

Sorace Roberta (robertasorace@yahoo.it): Faculty of Psychology I, University Sapienza, Via dei Marsi 78, 00185 Rome, Italy.

Solimeno Andrea (andrea.solimeno@uniromal.it): Faculty of Psychology I, University Sapienza, Via dei Marsi 78, 00185 Rome, Italy.

Tomai Manuela (manuelatomai@yahoo.it): Faculty of Psychology I, University Sapienza, Via dei Marsi 78, 00 I85 Rome, Italy. 